\title{
Conceptions and practices of embracement to the family members in psychosocial attention in alcohol and other drugs
}

\author{
Concepções e práticas de acolhimento aos familiares na atenção psicossocial em álcool e \\ outras drogas
}

\section{Concepciones y prácticas de acogimiento a parientes en la atención psicosocial en alcohol y otras drogas}

Gabrielle Leite Pacheco Lisbôa ${ }^{1}$, Mércia Zeviani Brêda ${ }^{1}$, Maria Cícera dos Santos de Albuquerque ${ }^{1}$

This is a qualitative research made from March 2012 to February 2014 to identify and to analyze conceptions and practices of embracement to the family members of the people who use drugs, from the family's and the professionals' perspective in a Psychosocial Attention Center specialized in Alcohol and Other Drugs in Maceió, AL, Brazil. Data collection was made by semi-structured interviews with the use of previously elaborated script. Bardin's thematic analysis and discussion approved by Merhy revealed it as an act of receiving. For professionals, it is an administrative reception, triage, and transfer of information. For the family members, it is always to be welcome. The practice, present in relations in which there is the encounter professional-user, materialized in family groups and listening. In the working process, embracement to the families expresses the need of qualified listening, constitution of bond and their co-responsibilities.

Descriptors: User Embracement; Family; Mental Health Services.

Pesquisa qualitativa, realizada de março de 2012 a fevereiro de 2014 para identificar e analisar concepções e práticas de acolhimento aos familiares de usuários de drogas, na perspectiva de familiares e de profissionais de um Centro de Atenção Psicossocial Álcool e Outras Drogas em Maceió, AL, Brasil. A coleta de dados foi realizada por entrevista semiestruturada com uso de roteiro previamente elaborado. A análise dos dados foi guiada por Bardin e sua discussão por referenciais de Merhy. Os resultados evidenciaram o acolhimento como ato de receber. Para profissionais, trata-se de recepção administrativa, triagem e repasse de informações. Para familiares, é ser bem recebido sempre. A prática, presente nas relações em que há o encontro profissional-usuário, materializa-se nos grupos de família e na escuta. No processo de trabalho, acolhimento às famílias expressa a necessidade da escuta qualificada, constituição de vínculo e corresponsabilizações.

Descritores: Acolhimento; Família; Serviços de Saúde Mental.

Investigación cualitativa, llevada a cabo de marzo de 2012 a febrero de 2014 para identificar y analizar las concepciones y prácticas de acogimiento a parientes de usuarios de drogas, en la perspectiva de parientes y de profesionales de uno Centro de Atención Psicosocial Alcohol y Otras Drogas en Maceió, AL, Brasil. La recopilación de datos fue por entrevista semiestructurada, con uso del guión previamente producido. El análisis temático fue guiado por Bardin y la discusión por Merhy. Los resultados revelaron acogimiento como acto de recepción. Para los profesionales, es una recepción administrativa, selección, transferencia de información. Para la familia, es ser bien recibido. La práctica presente en las relaciones en las cuales hay el encuentro entre usuario y profesional se materializa en grupos familiares y en la escucha. En el proceso de trabajo, acogimiento a las familias expresa la necesidad de escucha cualificada, constitución de vinculo y de corresponsabilizaciones.

Descriptores: Acogimiento; Familia; Servicios de Salud Mental.

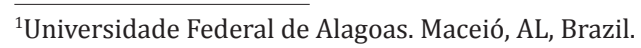




\section{Introduction}

In the current context, Brazil searches new alternatives for changes in the daily practices of health, in a constant attempt to make the principles of Unified Health System (UHS) possible and bring new manners to guarantee its functioning, able to respond to the need of the people who use the services of health.

One of the ways is the implementation of the National Policy of Humanization (NPH). Since 2003 such policy has proposed to foment principles and manner of operating in the set of relations between professionals and users, between the different professionals, between the several units and services of health and between the instances which constitute the UHS, for a transversal acting configured around the humanization of the practices of attention and management as a fundamental dimension of the health system ${ }^{(1)}$.

In this process of implementation, embracement is the guideline with the highest ethical, esthetic and political relevance of the $\mathrm{NPH}^{(2)}$. Embracement can have several aspects: it can be mistaken with the activities performed in the reception of unit of health or even with the triage in the services ${ }^{(1)}$. Its comprehension can still suffer a series of displacements (access, entrance door, emergency care), which go up to the limit of emptying its own meaning, being just a new name for an 'old' activity (in general, some kind of emergency care $)^{(3)}$.

Embracement, however, goes beyond all of that. It is not an area nor a venue, but an ethical posture; it does not presuppose time nor a specific professional to do it, but it implies knowledge sharing. It does not constitute a stage of the process, but it is an action which must occur in all the venues and moments of the health service ${ }^{(2)}$.

Embracement, as the guideline of the NPH, is configured as a techno-assistential action, which presupposes a change of the relation professional/ user and of the social net through technical, ethical, humanitarian and sympathetic parameters, recognizing the user as subject and as active participant in the process of production of health ${ }^{(2)}$.

Therefore, it is within the intercessor area (of encounter and intervention) of the worker/user, in which there is a game of interests (of the service, of the workers and of the users), expressed in the micropolicy of the work in health. In this game, its agents are present while socially and historically constituted man, with problems and need transferred to the scope of the services of health. In this area, certain availability may be present or not, especially of the workers, to build a more human relation based on the development of the potentialities of the people, mobilizing them or not for the use of the available technologies ${ }^{(4)}$ which favor the links.

In this sense, the technologies involved in the work in health can be classified as light( technologies of relations of production of link type, autonomy and embracing), light-hard (well structured knowledge, which operate in the process of work in health, such as medical clinic, epidemiology, etc...) and hard (as in the case of technological equipment like machinery, guidelines and organizational structures ${ }^{(5)}$.

After such classification, embracement is understood as light technology of the intercessor process of the work in health which occurs in all the places in which the encounters workers-users happen ${ }^{(5)}$, placing it, that way, in the sphere of the processes of work, which is revealed in the dynamics of the daily relations among professionals, users and family members of the service.

In the processes of work in the area of mental health, with the struggle for a psychiatric reform and the creation of substitute services, embracement becomes even more significant, once it implies being alert and open to the adversities ${ }^{(2)}$, to the establishment of the relations with the world, meaning of life, health, disease and care.

Among the substitute services, the Psychosocial Attention Center (PSAC) is highlighted, main strategy used for the attention to the person with psychic suffering. It is a open and communitarian health 
service of the UHS, whose practices are characterized by occurring in a cozy environment, with the objective to offer assistance to the population of this area of influence, and the purpose to have the clinical assistance and the social re-insertion of the users through the access to work, pleasures, exercise of civil rights and the strengthening of the family and communitarian bonds ${ }^{(6)}$.

In order to attend the specific demands of the population with problems resulting from the use of alcohol and other drugs, the Psychosocial Attention Centers specialized in Alcohol and other drugs (PSAC ad). For such, it develops intersectorial actions, and must be in constant movement and re-invention to provide universal and unconditional embracement ${ }^{(7)}$.

The problematic of the drug affects not only the people who make abusive use or are dependent, but also the ones who are closer to them. This because it interferes progressively in the affective bonds, jeopardizing the social relations, so that the family bonds become frail and frequently break up, marginalizing the subject progressively ${ }^{(8)}$.

It is up to PSAC to offer support to the family members $^{(7)}$ for the maintenance and strengthening of those bonds and it should reinforce and show the relevance of the presence of the family members at work, informing them that they are partners and coresponsible for the treatment of the user. It is for that participation that the adherence to the treatment is reached: from the bond and the mutual responsibility required $^{(9)}$.

So, in the current paradigm of psychosocial attention, it is not expected that the families simply live with the suffering subject, but also that can be comprehended in their difficulties to deal with such reality, from opportunities of participation and creation of strategies which effect the inclusion of the family members in the care rendered ${ }^{(10)}$.

Thus, the embracement can be used as a strategy of inclusion of the family in the context of the substitute services, because, from the bonds created in the areas of embracing and listening, the family can feel strengthened to deal with the psychic suffering and have the possibility to reorganize its familiar nucleus $^{(10)}$.

Considering the importance of the care rendered to the families, this study aimed at identifying and analyzing the conception and practices of embracement to the family members of people who use drugs, under the perspective of the PSAC ad professionals and of the family members assisted by such service.

The study used as reference a theoretical production in which embracement is considered a technology, and is inserted in the sphere of process of work, once it will occur whenever there is a established relation between worker and user(5,11-12).

\section{Method}

This is a study of qualitative approach, made between March 2012 and February 2014, which makes the comprehension and interpretation of this problematic possible, through the subjects and their meanings in the production of results ${ }^{(7)}$. The study was made in the Psychosocial Attention Center specialized in Alcohol and other drugs III (PSAC ad III) Dr. Everaldo Moreia, located in the city of Maceió (AL). The data collection was oriented using the interview technique, using a script as facilitator of the opening of the meeting; it was composed by trigger question, which introduced the thematic. The professionals were asked as follows: What is embrace for you? How do you identify that the embracement in being made? Could you describe how this embracement is? And to the family members: For you what is it to be embraced? How do you identify being embraced? Could you describe how this embracement is?

The interviews were recorded with the consent of the interviewees, they were transcript by the researcher himself, followed by a floating reading. The thematic analysis was used in order to discover the nuclei of senses which made up the communication 
of the subjects ${ }^{(13)}$. Merhy's perspective theory made weaving approximation with the process of work feasible, considered as strategic area in which the relation among the workers, users and family members of the service constitute embracement into action $^{(5,12)}$.

Six family members assisting the people being taken care of by PSAC ad III participated in the study, as well as eight professionals with university degree, who had their activities in the service and provided assistance to the family members, independently of the time of service in the unit of health.

The statement of the participants subjects are represented by $\mathrm{F}$ or $\mathrm{P}$ letter, for family members or professional respectively, followed by Arabic number corresponding to number of the interviewed subject. The subjects chosen for this study were the ones who accepted to participate in it and signed the Informed Consent Form (ICF). The subjects were chosen at random and the criterion of data saturation was considered $^{(14)}$.

The ethical principles of this research were respected according the resolution CNS/MS 466/12(15). The study was previously approved by the Committee of Ethics in Research and Teaching of the University Center CESMAC (COEPE) under protocol 1.574/12.

\section{Results}

Of the six family members of people assisted in the services interviewed in this research, five were female. They varied from 27 to 72 years of age, with an average of 50.5 years. Among these, three were mothers, the other three family members were represented by a wife, a grandmother and one father. As to the marital status, two were married, two single, one divorce and one widow. As to schooling, three were illiterate and could only write their own names; the other three were represented by family members that had university degree, high school and incomplete grade school.

Among the eight professionals of the PSAC who were interviewed, seven were female. The age varied from 25 to 45, with an average of $33.2 \%$ years, all single. The professional categories were represented as follows: two nurses, two social assistants, one occupational therapist, on psychologist, one physical educator and one doctor. The time of education varied from 8 months to 22 years, with an average of 9.3 years. The working time in the service varied from 1 week to 2 years, with an average of 8.5 months.

For both group of subjects embracement is considered essentially as an act of reception, as follows: Being embraced is being well received (F3). Being embraced is a time when we need to be well received (F4). It is when you are well receive (F5). What we call embracement here as PSAC is the moment of their arrival, where there is a responsible technician on that day for reception, so it is when we present what the proposition of PSAC is, because sometimes people come, but they don't know exactly what it is, which means, if we don't present the services and the groups we have here and how the person will fit in this therapeutical proposal(P6).

The professional understands that embracing is not just of the first moment, because the triage is made and it is in the first moment with the user, from then on embracement starts; so, the embracement, I believe it is from the moment he comes in until he is discharged of the service, it is continuous, it is the whole time, then we get to know how the user is, how his recovery is doing, or not, so you are going to identify and direct the treatment (P5). Among the practices revealed, embracement is to have a qualified listening, is when you understand that the subject is a unique being, when you embrace him, and from then on you create a bond (P2).

There is a relation between the embracement and the qualified listening, according to the professional's statement: In the individual assistance we have a qualified listening, we listen what they have to say, once we listen and make orientation. One example, yesterday the aunt want to know why the niece was hospitalized, what had happened, then she cried a lot and we let her cry, I say that it is normal, because it moves them(P2).

The qualified listening must be destitute of judgment. The professional understands that: we cannot judge, we cannot place religion, for example, ahead, because sometimes when we hear, suddenly the subject can say that may 
offend your religiosity, then you confront him. So, avoid making judgments, also fake judgments facing the truth and understand him in his religion, his integrity, I think that embracement must be neutral (P2). Sometimes he is very well embraced here, but then he faces an unprepared professional who might even be prejudiced (P3).

Concerning the need of non judgment, the family member reveals that what happens is: people embrace you very well. They are friendly. I don't see a critical look from them, no. It seems to be it is embracement (F1).

About the formation of bond with the family, the professional states: In general we try to obtain the maximum of information, asking for support, help, and the information concerning the family and at the same time creating a partnership and bonds (P8).

And he reveals the practice used for the construction of bonds in the family groups: There is the first moment that is here at PSAC, and always, the reunion of families, on Thursdays, to form a bond (P1).

For the professional of PSAC ad, within the family group, embracement is to put as active participant and give the maximum information for his acting, so that the family can give continuity to what is started here, and there is always a door, a support point, a door that will always be open for him to ask for help whenever needed (P8).

For the family member, the person must be well assistant, and require the thing too, he has to be committed, participate in the meetings. Many mothers here say: 'For F5 is so easy to get the things1' But why? Because when they tell me to go I go, when there is concerning the secretary or a lecture for us to go, and requires the presence of a mother or a family member, I am there (F5).

There is a co-responsibility mentioned also by the professional, when he states that: Embracement is when you receive the person and puts yourself at her disposal according to the resources that you can offer and, at the same time, that person who is being embraced can offer you, because embracement always needs a counterpart from the one who is embraced both in accepting the rules of the service as well as provide his counterpart so that the service can be effective (P4).

There is always the conception that to embrace is to receive this user, try to understand him, what brings him here to PSAC and from then on taking him to the service which corresponds to his needs, because not everyone who comes here needs the same treatment that is offered her (P6).

\section{Discussion}

Embracement is presented as a fundamental key to invert the logic of organization and functioning of the health service, based on the following principles: '1) Assist all the persons who look for the services of health, guaranteeing universal accessibility. So, the health service assume its first function, the embracement, the listening and give a positive response, able to solve the health problems of the population; 2) Reorganize the process of work, so that it moves central axis from the doctor to a multiprofessional team - embracement team - , which is responsible for listening to the user, being committed to solve his problem of health; 3) Qualify the relation worker-user, which must take place through humanitarian, sympathy and citizenship

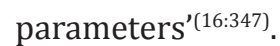

It still assumes the responsibility for the change of care centered on the hard technologies to a care which is turned to the user of light technologies, especially in the services of mental health. And because it makes the manifestation of the subjectivity of the other feasible is that currently it became indispensible to the valuing of light or related technology by the subjects who are part of the practice in the services of mental health, considering the changes resulting from the psychiatric reform and of the psychosocial attention $^{(17)}$.

From the analysis of the statements, conceptions and practices of embracement and their inter-relations in the process of work at PSAC ad were identified.

The embracement as an act of reception became evident being identified sometimes as a special dimension, which is translated as administrative reception and comfortable environment; sometimes as an action of administrative triage and the leading to specialized services. Such conceptions have different 
meaning for family members and professionals. When embracement is provided isolated in the process of work in health it takes us to punctual isolated actions which make evident or jeopardize responsibility and the bond ${ }^{(2)}$.

So, the conception of embracement, while light technology of the intercessor process of work in health is shared and this occurs in all places where there are the workers-users meetings ${ }^{(11)}$. Embracement is distinguished of triage because it does not constitute a stage of the process, but as an action, which must occur in all the venues and moments of the health service. For such reason, embracement does not presuppose time or specific professional to do it, implies sharing of knowledge, anguishes and inventions, taking for itself the responsibility of 'protecting and sheltering' the others in their demands, with responsibility and resolution ${ }^{(2)}$.

Even so, it is necessary to remember that no person feels embraced in an environment in which he is not well received. So, embracement happens in the first contact of the user in the service of health, inevitably at the reception. Embracement is, therefore, a continuous process, not only the stage of assistance which is provided at the doors of the services.

Regarding the continuity of the embracement, it is explicit that its practice occurs in the process of relation worker-user, in a continuum, especially in the domain of health in which the relations of care are established. In the working health, that is always relational, the relations which are established can be summary and bureaucratic, or can be considered as 'intercessors' relations established during the work, made in the care to health. The term 'intersection', in this case, designates what is produced in the relations among subjects, in the space of their intersections, which is a product that exists for the two working together and do not exist without the moment of relation in process, in which the participants place themselves as instituting subjects in the pursuit of new processes, even one regarding the other ${ }^{(12)}$.

The notion of embracement, which is adopted or assumed occasionally by concrete actors, reveals perspectives and intentions. In this sense, it is possible to state that embracement is a present practice in all the relations of care, in the real meetings between workers of health and users, in the acts of receiving and listening to the people, and this can happen in several ways ${ }^{(18)}$. The practice of care, through the statements of the researches is based on the triad of the light technologies of the process of work, that is: embracement qualified listening and bond ${ }^{(19)}$. The embracement, first element of the triad, is an intercessor process, which aims at the production of relations of listening and responsibilities, in which they articulate through the constitution of bonds and commitments in projects of intervention ${ }^{(16)}$.

So, in the process of work of PSAC ad, the embracement to the families still expresses, even more, the need of qualified listening, once the families who followed the process of chemical dependence of a dear member showed to be very fragile, shaken with the affective, economic and social matters which the drug brought inside the family.

The qualified listening provides reading between the lines and requires an internal disposition to embrace explicit signs as non explicit ${ }^{(19)}$. It exceeds the capitation of verbal messages. The worker, through the listening must the user beyond this complaint ${ }^{(4)}$. It still offers a positive response, able to solve problems and provide a relation of trust and support to the user, respecting the feeling, the ideas and the expectation of each subject ${ }^{(20)}$.

In the embracement to the families, the qualified listening means becoming entangled in the feeling, anguishes, fear, expectations, dreams and in everything that only the works could not ever express.

For this reason, when the service is open for a listening, it brings, to this routine of work, the dynamics experienced in the everyday lives of the families, transforming this act in a moment of interaction and sharing of knowledge.

In this relation worker-user, all kinds of judgment must be avoided, once they can put an 
end to what would be the formation of the bond and the establishment of a relation of trust, becoming necessary, from the moment in which listening is established, not to measure efforts to avoid the struggle of ideas or convictions between the parts.

For the family members, embracement permeates the idea of non judgment, also under non verbal expressions, like the look. When the service attends to this expectation of non judgment, it becomes much more embracing in the vision of the family members.

Returning to the triad of light technologies, we still find the bond, which concerns to the establishment of a relation of trust between who cares and who is assisted, being permeated also by the responsibility and the commitment.

It is also noticed that there is a transversal aspect between the formation of family-professional bonds and the qualified listening, once the family member has important information regarding the user who is attended by the service and the listening, here, shows itself as a powerful instrument of work, being recognized and used by the professional.

Besides that, the listening provides a mutual knowledge between the family member and the health professional. Thus, the formation of the bond assumes a fundamental role for the maintenance of the listening and of the relation between the subjects.

Establishing bonds, therefore, consists in the health professional having clear and closer relation with the user, being integrated with the community in its surroundings, in the service, in the doctor's office and in the groups, becoming a reference for the patient, individually or collectively, thus serving to the construction the autonomy of the user ${ }^{(4)}$.

Concerning the integration which occurs in the several venues where the relation between the subjects is established, the professionals reveal the formation of bonds also in the group of families. The participation of professionals in the group provides a relation of trust and bond, in which the same end up becoming a reference of care and attention.
For the team of PSCA ad, the group of families show itself as a privileged room for the participation of these subjects in the health service in which, through the exchange of experiences, knowledge and information, become possible to strengthen the subjects in their daily lives against chemical dependence and bring family members to the reality of the service on the pursuit of returning them to their autonomy.

The embracement and the bond make the construction of autonomy possible with the responsibility shared and agreed between the subjects involved. The construction of the autonomy happens when both can deal with their own nets of dependencies, co-production of himself and the context. In this case, the formation of the coresponsible attitude requires the commitment and the mutual agreement, avoiding daily dissonances in the possibility of living together and of working in favor of some proposal ${ }^{(17)}$.

The relation of care which is established between the health service and the family members favors the formation of the bond, besides the perception of the co-responsibility and of the necessary commitment for the maintenance of the relations between the subjects.

For the professionals of PSCA, in a relation in which there is the co-responsibility, the health professional gives to the family member all the arsenal of therapeutical interventions possible, while the embraced person must show involvement, participating actively in the pursuit of possible solutions for the resolution of their problem, giving a feedback to the service and contributing for the effectiveness of the care.

So, it is important to highlight that the embracement becomes feasible in the daily lives of the practices of health through the qualified listening and the capacity of agreement between the demand of the user and the possibility of response of the service. It must be translated in qualification of the health production, being complemented with 
the responsibility of what can not be immediately responded, but which is possible to direct an ethical and resolutive way, with access security for the user ${ }^{(2)}$; once the relation worker-family member-user occurs under humanitarian parameters of sympathy and citizenship $^{(5)}$.

\section{Final Considerations}

The conception and practices of embracement are inter-related with the process of work, once the same significantly influence this one. Besides that, the process of work is a strategic place of changes, in which, through the professionals-family members-users relations, is possible to fight for the commitment with life, being the real needs attended in an embraceable manner, establishing the qualified listening, aiming at strengthening the bonds with co-responsibility and giving the autonomy of the subjects back.

In this study becomes evident the conception of the embracement as an act of reception, assuming different meaning for the family members and professionals. It revealed as light technology of the relational processes, does not requiring a specific professional, day or time to happen.

It is a practice of care present in all the relation in which there is the meeting professional-user, that is materialized in the qualified listening, the bond, the co-responsibility and commitment, and, in the search for autonomy. The value of the group of support to the families is still highlighted, which constitutes privileged room for the insertion and participation of those families in the services.

This study does not exhaust the debate concerning the thematic under question and opens spaces for possible future investigations. While promoting an auto-reflection of the professionals and family members on the embracement, it evokes the intervention in the objective reality, the improvement of the inter-personal relations, modification in the processes of work, strengthening the bonds in order to make the assistance in PSAC ad truly embraceable.

\section{Collaborations}

Lisbôa GLP contributed for the conception of the study, data collection, analysis and interpretation of the data, writing of the article and final approval of the version to be published. Brêda MZ contributed for the conception and orientation of the study, writing of the article and final approval of the version to be published. Albuquerque MCS contributed for the writing of the article and final approval of the version to be published.

\section{References}

1. Brehmer LCF, Verdi M. Acolhimento na Atenção Básica: reflexões éticas sobre a Atenção à Saúde dos usuários. Ciênc Saúde Coletiva. 2010; 15(Supl 3):3569-78.

2. Ministério da Saúde (BR). Secretaria de Atenção à Saúde. Núcleo Técnico da Política Nacional de Humanização. Acolhimento nas práticas de produção de saúde. Brasília: Ministério da Saúde; 2010.

3. Teixeira RR. 0 acolhimento num serviço de saúde entendido como uma rede de conversações. In: Pinheiro R, Mattos RA, organizadores. Construção da integralidade: cotidiano, saberes e práticas em saúde. Rio de Janeiro: IMS-UERJ/ABRASCO; 2010. p. 89-111.

4. Matumoto S, Mishima SM, Fortuna CM, Pereira MJB, Almeida MCP. Preparando a relação de atendimento: ferramenta para o acolhimento em unidades de saúde. Rev Latino-Am Enfermagem. 2009; 17(6):1001-8.

5. Merhy EE, Chakkour M. Em busca de ferramentas analisadoras das tecnologias em saúde: a informação e o dia a dia de um serviço, interrogando e gerindo trabalhos. In: Merhy EE, Onocko R, organizadores. Agir em saúde um desafio para o público. $3^{\mathfrak{a}}$ ed. São Paulo: Hucitec; 2007.

6. Azevedo DM, Miranda FAN. A representação social de familiares nos Centros de Atenção Psicossocial. Esc Anna Nery. 2011; 15(2):354-60.

7. Ministério da Saúde (BR). Abordagens terapêuticas a usuários de cocaína/crack/ no Sistema Único de Saúde. Brasília: Ministério da Saúde; 2010. 
8. Seleghim MR, Marangoni SR, Marcon SS, Oliveira MLF. Family ties of crack cocaine users cared for in a psychiatric emergency department. Rev LatinoAm Enfermagem. 2011; 19(5):1163-70.

9. Azevedo DM, Miranda FAN. Oficinas terapêuticas como instrumento de reabilitação psicossocial: percepção de familiares. Esc Anna Nery. 2011; 15(2):339-45.

10. Mielke FB, Kohlrausch E, Olschowsky A, Schneider JF. A inclusão da família na atenção psicossocial: uma reflexão. Rev Eletr Enf. [periódico na Internet]. 2010 [citado 2014 fev 11]; 12(4):7615. Disponível em: revistas.ufg.br/index.php/fen/ article/view/6812

11. Lima LL, Moreira TMM, Jorge MSB. Produção do cuidado a pessoas com hipertensão arterial: acolhimento, vínculo e corresponsabilização. Rev Bras Enferm. 2013; 66(4):514-22.

12. Merhy EE. Saúde: a cartografia do trabalho vivo. São Paulo: Hucitec; 2002.

13. Fontanella BJB, Lechesi BM, Saidel MGB, Ricas J, Turato ER, Melo DG. Amostragem em pesquisas qualitativas: proposta de procedimentos para constatar saturação teórica. Cad Saúde Pública. 2011; 27(2):389-94.

14. Bardin L. Análise de conteúdo. São Paulo: Edições 70; 2011.
15. Ministério da Saúde (BR). Conselho Nacional de Saúde (CNS). Resolução CNS/MS no 466 de 12 de dezembro de 2012, que aprova diretrizes e normas regulamentadoras de pesquisas envolvendo seres humanos. Brasília: Ministério da Saúde; 2012.

16. Franco TB, Bueno WS, Merhy EE. 0 acolhimento e os processos de trabalho em saúde: o caso de Betim, Minas Gerais, Brasil. Cad Saúde Pública. 1999; 15(2):345-53.

17. Jorge MSB, Pinto DM, Quinderé PHD, Pinto AGA, Sousa FSP, Cavalcante CM. Promoção da saúde mental - tecnologias do cuidado: vínculo, acolhimento, co-responsabilização e autonomia. Ciênc Saúde Coletiva. 2011; 16(7):3051-60.

18. Ministério da Saúde (BR). Secretaria de Atenção à Saúde, Departamento de Atenção Básica. Acolhimento à demanda espontânea. Brasília: Ministério da Saúde; 2013.

19. Oliveira FB, Silva JCC, Silva VHF, Cartaxo CKA. O trabalho de enfermagem em saúde mental na estratégia de saúde da família. Rev Rene. 2011; 12(2):229-37.

20. Coimbra VCC, Nunes CK, Kantorski LP, Oliveira MM, Eslabão AD, Cruz VD. The technologies used in the working process of the psychosocial care unit with sights to reach the comprehensiveness. R Pesq Cuid Fundam. 2013; 5(2):3876-83. 